\title{
Improvement of Teacher Professionalism
}

\author{
Iqbal Afrizal Noris \\ Department of Educational Management \\ Universitas Negeri Surabaya \\ Surabaya, Indonesia \\ iqbalafrizal4@gmail.com
}

\begin{abstract}
Increasing the professionalism of teachers was related to the ability of teachers to teach knowledge and management of learning. Ways that can be done in improving the quality of learning by conducting classroom action research. Class action research is a research activity to solve learning problems. The purpose of this training is to discuss the knowledge and practices of Classroom Action Research. This study used a qualitative method. Data collection techniques, interview, observation, coordination, and tests, with data analysis techniques using data techniques to reduce, data presentation, and conclusions. From the results of the overall evaluation of the implementation of the Classroom Action Research training is fairly successful, it can be seen from the results during the training to show participants enthusiasm, as well as implementation indicators and the results obtained from the training.
\end{abstract}

Keywords-professionalism; training; classroom action research

\section{INTRODUCTION}

Improving the quality of education is felt as a necessity of the nation who wants to progress, with the belief that quality education can support quality in all fields. Therefore, education needs to be given great attention so that we can catch up in the field of science and technology that we absolutely need to accelerate development today. Therefore, quality education needs to get serious attention from the government. Teachers play a strategic role, especially in efforts to shape the character of the nation through the development of personalities and desired values. From this dimension, the role of the teacher is difficult to replace by others. Through education the nation's intellectual education program can be improved and developed. Improving the quality of education carried out in various ways, one way is to increase the ability of teachers to involve students in the learning process. In the learning process, there is a need for interest in learning, without good interest there will not be a correct learning process. Interest in student grades is very important in achieving learning success, interest formed since childhood is often carried away for life [1].

The spirit of implementing ideal learning in accordance with the curriculum used, is often constrained by the reality that many teachers encounter when in the classroom. The problems encountered are actually rooted from year to year, namely the atmosphere of learning is not conducive, students are less enthusiastic, less attention to learning, unskilled, student activities to take lessons are quite low, active students are only monopolized by certain students, students are busy or play alone, sleepy, not enthusiastic and tend to behave in a negative direction, the learning process is less interactive, students are not able to understand the concept correctly so that student learning outcomes are not in accordance with what is expected or under the Minimum Criteria. Not to mention the problems that arise from the teacher, namely the lack of mastery of the teacher in the classroom, low understanding and provision of knowledge to explain the subject matter, monotonous teaching methods, poor ideas and creativity in teaching, and rarely use learning media [2]. Improving the quality of learning carried out by teachers can be done through classroom action research. With classroom action research, the learning presented by the teacher will be more effective. Classroom action research is also a teacher's need to improve his professionalism as a teacher. Classroom Action Research is research that combines research procedures with substantive action, an action taken in the discipline of inquiry or an attempt by someone to understand what is happening, while engaging in a process of improvement and change [3].

Regarding this need, the purpose of this paper is to plan and evaluate classroom action research. This research is expected to be able to contribute to teachers and teachers as a reference for solving problems in the classroom at SDIT (Islamic Integrated Elementary School) Nurul Hikmah Sidoarjo.

\section{METHOD}

This study uses a qualitative method. The use of this qualitative method aims to describe how the research process through training activities Research case study design that aims to describe and obtain clearly the focus of this research [4]. The location of this study was carried out at SD (elementary school) Nurul Hikmah Sidoarjo with the object of the research being the teacher and headmaster of SDIT (Islamic Integrated Elementary School) Nurul Hikmah Sidoarjo. Types and Sources Data obtained in this study are qualitative data. Qualitative data from this research is in the form of data obtained from teacher activities in the form of data from interviews, observation and documentation during the implementation process.

To explain and describe the results of the study in accordance with the focus of the study, it is necessary to collect a number of relevant data using a data collection technique. Data collection techniques function in obtaining data in conducting research, so without knowing the data collection techniques, researchers will not get data that meets the specified data standards. Data collection techniques conducted by researchers in three ways, namely 1) the interview, the researcher used semi structured interview with teachers at the time of the 
determination of the research and when the study was in progress; 2) observations, made during the activities of the learning takes place. Its implementation is done by filling the format which has been prepared by researchers with the purpose to determine the activity and behavior of the subject of research at the time of the learning takes place; 3) Documentation, researchers take documents when the study takes place, the document is a record or archive of an event that has been done or is valid; 4) tests, researchers did tests simple to collect information about the understanding of teachers about the material that is taught to the teachers. The test consists of the initial test and the final test [5].

Research instrument can collect the data or information to declare: the purpose of research, namely in the form of means of recording, documentation photos, results of tests, etc.

Data analysis in this study was carried out after data collection. The stages of qualitative data analysis activities are a) Reducing data, Reducing data is the process of selecting, focusing, and simplifying all data that has been obtained, starting from the initial data collection to the preparation of research reports; b) Presenting data, Reducing data is the process of selecting, focusing, and simplifying all data that has been obtained, starting from the initial data collection to the preparation of research reports; and c) Draw conclusions and verification. withdrawal conclusion is the appearance of the essence of the results of the interpretation and evaluation. This activity includes searching for data meanings and giving explanations. Further verification is carried out, namely testing the truth, robustness, and compatibility of the meanings that emerge from the data. Verification of data intended to evaluate all the information that has been obtained some data obtained by the data of informants, so that would be obtained a data validity and quality as well as the results of the data that can accounted for righteousness [5].

\section{RESULTS AND DISCUSSION}

To find out the school needs, the researcher analyzes the needs of each teacher by coordinating with the principal using interviews, observations, instrument questionnaires. Schools expressed very concerned related to the competence of teachers in the preparation of research action class because can help to improvements in the process of learning to teach in class. The teachers at school are very enthusiastic with the presence of researchers because of bias adds to insight them about the importance of research of action class. The teachers at school is already doing research action class but not optimal when viewed from the period of time each study was conducted by teachers.

Teachers are already doing efforts to reform, innovation in learning to support improvements in learning, but is considered still not optimal and the required effort and consistency that is more to achieve the objectives which they expect. Evaluation of research was carried out using reaction, learning, behavior, and result, which was proposed by Kirkpatrick [9].
Before carrying out the research, first do the planning using the Need Assessment Training which includes, namely organizational, occupational and individual levels using interviewing techniques, observation, giving work instrument questionnaires [6]. At the stage of teacher assessment Need Analysis Training activities at SDIT (Islamic Integrated Elementary School) Nurul Hikmah Sidoarjo, researchers coordinated with the Principal to determine what training would be needed by teachers at school. After coordinating with the school, the researcher conducted an instrument test through Google Form as an initial means of determining teacher needs. After conducting interviews with the principal and accompanied by the results of the questionnaire / instrument getting the results that the teachers in the school wanted to do the Classroom Action Research.

The school states that it is very concerned about the competence of the Class Action Research preparation. Conducting action research is one of the competencies that teachers must have is professional competence. Action research is a research conducted by practitioners with the aim of improving their professional practice and understanding it better. Classroom Action Research as part of action research, which aims to improve the quality of classroom learning practices, is increasingly in demand. Not a few educators conduct action research in their efforts to develop their profession. Therefore, more knowledge is needed.

From the results of observations made by researchers, it is indeed a good reaction, because the delivery of what researchers do is easy to understand and makes teachers understand the importance of action research in order to increase their professionalism, especially if it is related to learning. Action research aims to achieve three things, namely: (a) improved practice; (b) professional development or improvement of practical understanding by practitioners; and (c) improving the situation where the practice is implemented [7]. The success of an action can be measured by seeing its benefits. Likewise, also the research of action class, in addition aimed at improving and or improve the process of learning in the classroom success is measured on the expediency of action alternatives for the repair of the. Teachers are always dealing with students who vary each year. By reason was that teachers conduct research action class departing from the problems that faced in its class and produce a solution to the problem. With the process of learning in the classroom as the teachers are already doing innovative learning. From the aspect of the development of curriculum, research action class also can be used as effectively by teachers. Class teachers must be responsible for curriculum development at the school and class level, classroom action research will be very useful [8].

To see the results of this training have had an impact or not on the trainees the researchers gave pre-test and post-test to the participants. From the results of the pretest and posttest, the results showed that there was an increase in each teacher. With the results of the pre-test and post-test the training in SDIT (Islamic Integrated Elementary School) Nurul Sidoarjo can be said to have an impact on the trainees when viewed from the aspect of knowledge about benefits, and the importance of the principle of improving the quality of learning. Therefore, because the teacher or trainee has received sufficient 
provisions, the teacher and the school are expected to be able to implement the training obtained by designing their own researchers by utilizing existing Information Technology in schools with the aim of improving the quality of learning in the classroom.

From the experience of doing research, the teacher realizes his shortcomings and tries to make improvements and changes and improve his abilities. The teacher is aware of the need for renewal efforts, innovation in learning to support improvement. Through the experience of conducting research, the teacher understands the relationship between ideas or theories with teacher teaching and student learning practices in his daily life, and this awareness will foster self-confidence in the teacher, then increase to a sense of self-esteem and the quality of teacher professionalism.

At the evaluation stage it has been carried out with the planning of the instruments used quite complete, but from the results of the analysis the researchers found the evaluation to be imperfect because it is not like the theory that should be used, only using instrument questionnaire methods, observation, and reflection. Based on the results of interviews with the organizers, in this case only the main sub-items used in the training were taken, but it would be more valid if they included the above aspects as revealed by [6]. The evaluation was carried out with 4 and went well with reaction, learning, behavior, and result [9].

Evaluation of reaction carried out to measure the level of satisfaction of participants of the training on the implementation of the training, evaluation of learning stage into two is aimed to gauge the level of understanding of the participants on the matter of training or the extent to which power absorption teacher in material of training that has been given, while the evaluation of behavior can be done through observation directly to in the environment of teachers, through an interview with the head of the school and teacher another. To determine changes in the behavior of the work of participants before and after participating the program [10]. The evaluation results aim to determine the impact of changes in the work behavior of trainees on the level of organizational productivity. Aspects that can be targeted in this evaluation include increasing production, improving product quality, reducing costs, decreasing the number of work accidents in both quality and quantity, decreasing turnover, and increasing profit rates. Evaluation activities are carried out before, during and after this training activity takes place. The evaluation before the activity is carried out by conducting discussions with the teacher before the presentation of the material begins, while the evaluation during the activity takes place by observing the teacher when the training takes place. And after that an evaluation is carried out by repeating the material that has been given and each teacher makes the initial design of the research that they want to submit.

The idea of classroom action research as a medium to increase teacher professionalism in reality is not as expected, because there are still many obstacles in implementation. This constraint can be in the form of teacher's lack of understanding on how to implement and write class action research, busy teacher schedules so that they do not have time to conduct research, teacher mindset that this is difficult and teachers who do not understand the benefits of implementation should not continue for the continuity of the learning good in class.

\section{CONCLUSION}

Classroom Action Research is one type of development activity teacher profession. This type of research is basically a research activity implemented by the teacher in his class and the results can be used for improve the quality of learning practices. Classroom action research aims to improve quality the process and learning outcomes of students in their classrooms and schools. Classroom action research is an important part of the effort to develop the teacher's profession because it is able to teach teachers to think critically and systematically, and to teach teachers to write. For this reason, it is necessary for teachers to continually strive to conduct classroom action research for the improvement / improvement of their learning in the classroom and self-development as professional teachers.

Overall the implementation of Classroom Action Research training at SDIT (Islamic Integrated Elementary School) Nurul Hikmah Sidoarjo is quite successful, it is seen from the implementation indicators and the results obtained from this training with fairly good values, overall implementation is very good besides the implementers of the training give the best ability when the training starts and the teachers who become trainees are very enthusiastic from the beginning to the end listening to the material and direction from the training implementers. Therefore, the training implementing researcher expects that teachers at SDIT (Islamic Integrated Elementary School) Nurul Hikmah Sidoarjo can make implementing each year for self-development and improving the learning process in the classroom to create quality and become an example for other schools.

\section{REFERENCES}

[1] S. Saiful, "Konsep dan Makna Pembelajaran: Untuk Membantu Memecahkan Problematika Belajar dan Mengajar, cet IV," Bandung Alf., 2006.

[2] S. E. P. Widoyoko, "Evaluasi program pembelajaran: panduan praktis bagi pendidik dan calon pendidik. Yogyakarta: Pustaka Pelajar.” 2013.

[3] D. Hopkins and E. Ahtaridou, "A teacher's guide to classroom research," 1993.

[4] J. M. Lexy, "Metode Penelitian Kualitatif Ed. Revisi." Bandung: PT. Remaja Rosdakarya, 2012.

[5] M. B. Miles, A. M. Huberman, and J. Saldaña, "Qualitative data analysis: A methods sourcebook. 3rd." Thousand Oaks, CA: Sage, 2014.

[6] J. P. Wilson, Human resource development: learning \& training for individuals \& organizations. Kogan Page Publishers, 2005.

[7] S. Kemmis, R. McTaggart, and R. Nixon, The action research planner: Doing critical participatory action research. Springer Science \& Business Media, 2013.

[8] M. Kadarisman, Manajemen Pengembangan Sumber Daya Manusia, ed. 1. Cet. 1. Jakarta: Rajawali Press, 2012.

[9] D. I. Kirkpatrick., Evaluating training program: the four level. California: Barrett Kohler Publisher, 1988.

[10] J. C. McDavid, I. Huse, and L. R. L. Hawthorn, Program evaluation and performance measurement: An introduction to practice. Sage Publications, 2018. 